\title{
SUMMARY AND IMPLICATIONS FOR ACADEMICS, POLICY MAKERS, AND PRACTITIONERS
}

\section{Christine Schliesser, S. Ayse Kadayifci-Orellana, and Pauline Kollontai}

Religion matters in conflict and conflict resolution. Effective conflict resolution is too complex an endeavor to forego the contributions of any relevant actor, religious or not. It is therefore vital to better understand the role of religion in conflict and to strengthen religion's positive contributions for conflict resolution. It is in the joint collaboration of academics, policy makers, and practitioners, religious and secular, that the potential for change is astounding.

\section{IMPLICATION 1: BRIDGING THE DIVIDE BETWEEN RELIGIOUS AND SECULAR}

Effective conflict resolution depends on both religious and secular actors. Each must overcome ignorance and prejudices in order to collaborate successfully. For secular actors in government, business, media, and higher education, this calls for strengthening religious literacy. For religious actors, this means endorsing a theology that promotes the public and collaborative sides of religion. 


\section{IMPLICATION 2: BRIDGING THE DIVIDE BETWEEN DIFFERENT FAITH TRADITIONS}

Besides the necessity for bridging the religious-secular divide, there is a need for more and deeper cooperation between different faith traditions in conflict resolution. More often than not, ignorance and prejudices hinder interfaith cooperation. Interfaith dialogue and joint initiatives, however, can serve as powerful inspirations for overcoming violence not only within a particular conflict but also far beyond it.

\section{IMPLICATION 3: BRIDGING THE DIVIDE BETWEEN ACADEMICS, POLICY MAKERS, AND PRACTITIONERS}

Effective conflict resolution depends on the collaborative efforts of all relevant actors-academics, policy makers, and practitioners. Joint and cross-over efforts in higher education, governments, nongovernmental organizations (NGOs), and faith-based organizations (FBOs) need to be supported.

\section{IMPLICATION 4: MORE EVALUATION}

Despite the increasing number of programs focusing on religious peacebuilding, there is a knowledge gap in the area of evaluation. Evaluation of religious peacebuilding generates better understanding of what is effective religious peacebuilding and supports evidencebased policy and practice.

\section{IMPLICATION 5: BETTER INCLUSION OF WOMEN}

Women are often marginalized in conflict resolution processes, and consequently their perspectives and experiences are excluded. Recent studies show, however, that women are particularly effective agents of social change and conflict resolution. 


\section{IMPLICATION 6: BETTER INCLUSION OF THE YOUTH}

At the same time, more attention in conflict resolution theory and praxis must be directed towards the youth. The so-called "youth bulge" in many countries of the Global South has already given rise to concern about the potential destabilizing effect. The same goes for concerns about the growth of destablizing and anti-democratic ideologies such as racism, white supremacy, and Islamophobia amongst youth in the Global North. At the same time, the tremendous potential for conflict resolution and reconciliation within children and youth goes largely neglected.

\section{IMPLICATION 7: BETTER ENGAGEMENT OF THE MEDIA}

Conflict resolution in general, and religious conflict resolution in particular, need to become better in strategically engaging the media and social media. While there is no shortage of media outlets preaching religious hatred and intolerance, religious peacebuilders have to catch up in employing these powerful instruments for the means of peace, empathy, and acceptance of the other.

\section{IMPLICATION 8: TAKING THE ISSUES OF PROSELYTIZATION AND INSTRUMENTALIZATION INTO ACCOUNT}

Religious actors often face the charge that their main goal is to attract followers and convert others, which can constitute a serious impediment to peacebuilding between religious groups. At the same time, one needs to acknowledge that conversion is not an exclusively religious phenomenon as all development organizations aim to transform the way people act and think in terms of citizenship for the common good. This sensitive subject should therefore be treated in a differentiated manner and framed under the aspects of transparency and equality. 


\section{IMPLICATION 9: BETTER ENGAGEMENT OF INDIGENOUS AND NON-ABRAHAMIC RELIGIONS}

With much of Western attention focusing on the Abrahamic religions-Judaism, Christianity, and Islam-in conflict resolution, little attention is being paid to the contributions of indigenous, dharmic, and other East Asian religious traditions. Similar to Abrahamic faiths, these traditions have a wealth of resources and values that promote peacebuilding and justice. 